\title{
New trends in polymer electrolytes: a review
}

\author{
Neelam Srivastava, ${ }^{1^{*}}$ Tuhina Tiwari ${ }^{2}$ \\ "Mahila Maha Vidyalaya, Banaras Hindu University, Varanasi-221005; tel: 09194 \\ 15424782; e-mail: neelamsrivastava_bhu@yahoo.co.in, tuhina_tiwari@rediffmail. \\ com
}

(Received: 27 November, 2008; published: 28 December, 2009)

\begin{abstract}
Since the work of Armand, polymer electrolytes have received great attention and lots of publication can be found in the literature. Each publication has its particular orientation and tries to emphasize only limited points to prove their system as the better one. But to really get some good fruitful material we need to look simultaneously for different aspects of the electrolyte such as good conductivity and mechanical property, understanding of interaction between the salt and other materials present in the system, nature of solid electrolyte/ electrode interface, electrochemical window, working temperature window etc. Hence a brief summary of the variety of polymer electrolytes is given in the paper with their advantages and disadvantages. Paper discusses polymer electrolytes starting from Dry SPE to the latest IL/Zwitterionic electrolytes and the behavior of the some devices using these materials.

Key Words: Solid Polymer electrolytes, Gel Polymers, Composite Polymers, Ionic Liquids and Zwitterionic Polymers
\end{abstract}

\section{Introduction}

In the, fast growing development process of electrochemical devices (battery, solar cell, electro-chromic devices, super capacitor etc) [1], electrolyte has a very crucial and important place [2]. It has to play many roles like mechanical separator, an electronic insulator, a good ionic conductor etc. Hence while searching for a new electrolyte, conductivity does not remain the sole property, one has to look for many other properties like target ion transference number, electrode/electrolyte interface nature, electrode wet-ability, electrochemical and thermal stability window, packing flexibility, shelf life of material, possibility of getting thin film etc. Lots of electrolytes like lonic salts, glasses, ceramics, polymers etc have been tried for electrochemical application. But in the world leading towards miniaturization, the polymer electrolytes are receiving major attention [3, 4]. Polymers have viscoelastic nature which combines both liquid and solid like behavior making it very suitable for commercial applications. As they comprise the mechanical and technological properties of plastics they can be formed and molded in complex shapes and structures. Well developed and cost effective manufacturing processes are available for them. The modification of polymer matrix can be done by using plasticizer/fillers and/or blending, co-polymerization. This gives flexibility to designing.

Armand and co-workers [5] had first time shown the importance of the field. Since then scientists are trying to explore this technically important field. Polymers have shown a path towards the leak proof energy storage devices competing with liquid energy storage system. A lot of energy systems using these electrolytes are available in the market $[6,7]$. The reason behind this is the ability of polymers to be in solid 
with advantage of conventional liquid electrolyte's amorphous nature. An electrolyte has to play many important roles in electrochemical devices and requirement of each role is different from others e. g. conductivity needs amorphous/ flexible matrix but beyond a limit handling problem comes into picture. Electrolytes need to be compatible with electrodes, have wide electrochemical window, be compatible with working environment (temperature and humidity), be safe to human body, inflammable, non-explosive, ready to be abused due to mishandling, long working hours and many more. Thrust for getting an all in one electrolyte has encouraged scientist's worldwide to work hard and as a result large numbers of publications with different objectives are available in the field $[8,9,10,11,12]$. In this paper author's effort is to give a short scenario of present day's trend of the field. Polymer electrolytes can be broadly divided into three groups.

\section{Dry or solvent free SPE}

The Polymer electrolytes which are prepared through liquid phase but ultimately in solid form are known as dry or solvent free SPE. These types of electrolytes consist of PEO (and similar type polymer such as PESc, PPO, PEI, PMEEGE, PMEEMA, PVA, MEEP etc $[8,9,10,11,12]$ and some suitable salt. The PEO [13] has been found to be the most successful host material for such type of SPE. The reason behind this is the distance between hanging ether oxygen, which is very important in the salt dissociation and charge transport. Increasing the distance lowers down the charge transport possibilities where as decreasing it i.e. increasing the number of ether oxygen increases its interaction with cations resulting in low mobility and low number of mobile charge carriers. Being the most studied polymer electrolyte, literature is full of detailed reviews $[8,9,10,11,12]$ on dry polymer electrolytes. Hence authors have avoided going in details. Only a brief outline of the work is covered here. Some typical example of Dry SPE and their conductivity is given in Table (1) [14-31]. A standard method of preparing the SPE is shown in Fig. 1. Conductivity of such SPEs is roughly between $10^{-8}$ to $10^{-5} \mathrm{Scm}^{-1}$ which is not good enough for commercial energy storage devices. Hence a continuous hunt for better material is an ongoing process.

Conductivity of any electrolyte depends upon the i) the number of mobile charge carriers, ii) the medium available to assist their movement and iii) the nature \& charge on the mobile charge carrier. For electrochemical process the ionic transference number is a very important factor and ideally/theoretically $t_{\text {cation }}$ should be $~ 1$. The conductivity of PEO based electrolytes were not very good because of [32] i) crystalline phases present in the PEO ii) low melting point of PEO iii) strong interaction of ether Oxygen with cation hinders its movement which not only lowers down the total conductivity but simultaneously it decreases the $t_{\text {cation }}$ because cation is attached with oxygen.

To increase the conductivity it has been tried to suppress crystalline part of polymer chains to achieve better polymer chain mobility hence the fast cation movement. This is being done by processes like cross linking, copolymerization, comb formation, polymer grafting [33], polymer alloying (including inter penetrating network), inorganic filler blending etc. Table 2 [34-59] summarizes some of the results.

Increase of charge carriers can be realized by use of highly dissociable salts or by increasing salt concentration etc. 
Tab. 1. Examples of dry polymer electrolyte.

\begin{tabular}{|c|c|c|c|c|}
\hline S.No & Electrolyte & $\begin{array}{l}\text { Conductivity } \\
\text { S/cm }\end{array}$ & $\begin{array}{l}\text { Temp } \\
\mathrm{C}\end{array}$ & Ref \\
\hline 1 & PEO & $3.38 \times 10^{-8}$ & 25 & 14 \\
\hline 2 & $\mathrm{PEO}+\mathrm{NaClO}_{3}$ & $3.36 \times 10^{-7}$ & 30 & 15 \\
\hline 3 & $\mathrm{PEO}-\mathrm{Li} /\left(\mathrm{EC} / \mathrm{PC}-\mathrm{SiO}_{2}\right)$ & $2 \times 10^{-4}$ & R.T. & 16 \\
\hline 4 & $\mathrm{PEO}+\mathrm{LiClO}_{4}+\mathrm{TiO}_{2}$ & $1.40 \times 10^{-4}$ & 30 & 17 \\
\hline 5 & $\begin{array}{l}\text { Poly(dimethyl siloxane-g- } \\
\text { oligoethylene oxide) }\end{array}$ & $>10^{-4}$ & 25 & 18 \\
\hline 6 & $\begin{array}{l}\text { Borate polymer containing } \\
\text { fluoroalkane dicarboxylate\&PEO }\end{array}$ & $2 \times 10^{-6}$ & 30 & 19 \\
\hline 7 & Porous PVDF/LiClO & $\sim 10^{-3}$ & R.T. & 20 \\
\hline 8 & PPI:LiTF & $\sim 10^{-4}$ & 70 & 21 \\
\hline 9 & $\mathrm{PEO}_{6}: \mathrm{NaPO}_{3}+\mathrm{PEG}_{400}$ & $8.9 \times 10^{-7}$ & 37 & 22 \\
\hline 10 & $\mathrm{HPG} / \mathrm{PU} / \mathrm{LiClO}_{4}$ & $6.6 \times 10^{-4}$ & 60 & 23 \\
\hline 11 & PVA/Nal & $1.02 \times 10^{-5}$ & 30 & 24 \\
\hline 12 & $\begin{array}{l}\text { lonic plastic } \\
\text { crystal }\left(\mathrm{N}_{1223}\left[\mathrm{CF}_{3} \mathrm{BF}_{3}\right]\right)+\mathrm{Li}\left[\mathrm{CF}_{3} \mathrm{BF}_{3}\right.\end{array}$ & $10^{-4}-10^{-3}$ & R.T. & 25 \\
\hline 13 & $\mathrm{PVdF} / \mathrm{PVC} / \mathrm{EC} / \mathrm{PC} / \mathrm{LiClO}_{4}$ & $\sim 10^{-3}$ & R.T. & 26 \\
\hline 14 & $\mathrm{P}(\mathrm{EO} / \mathrm{MEEGE})+\mathrm{LiTFSI}$ & $1.4 \times 10^{-3}$ & 60 & 27 \\
\hline 15 & $\mathrm{P}(\mathrm{EO} / \mathrm{MEEGE})+\mathrm{LiTFSI}$ & $10^{-3}$ & 80 & 28 \\
\hline 16 & PEO-LiCF $\mathrm{SO}_{3}$ & $1.36 \times 10^{-6}$ & R.T. & 29 \\
\hline 17 & $\mathrm{PAN} / \mathrm{CN}-\mathrm{PVA} / \mathrm{LiClO}_{4} / \mathrm{PC}$ & $14.6 \times 10^{-3}$ & 30 & 30 \\
\hline 18 & PEO-LiClO $-\mathrm{ZnAl}_{2} \mathrm{O}_{4}$ & $2.23 \times 10^{-6}$ & 25 & 31 \\
\hline
\end{tabular}

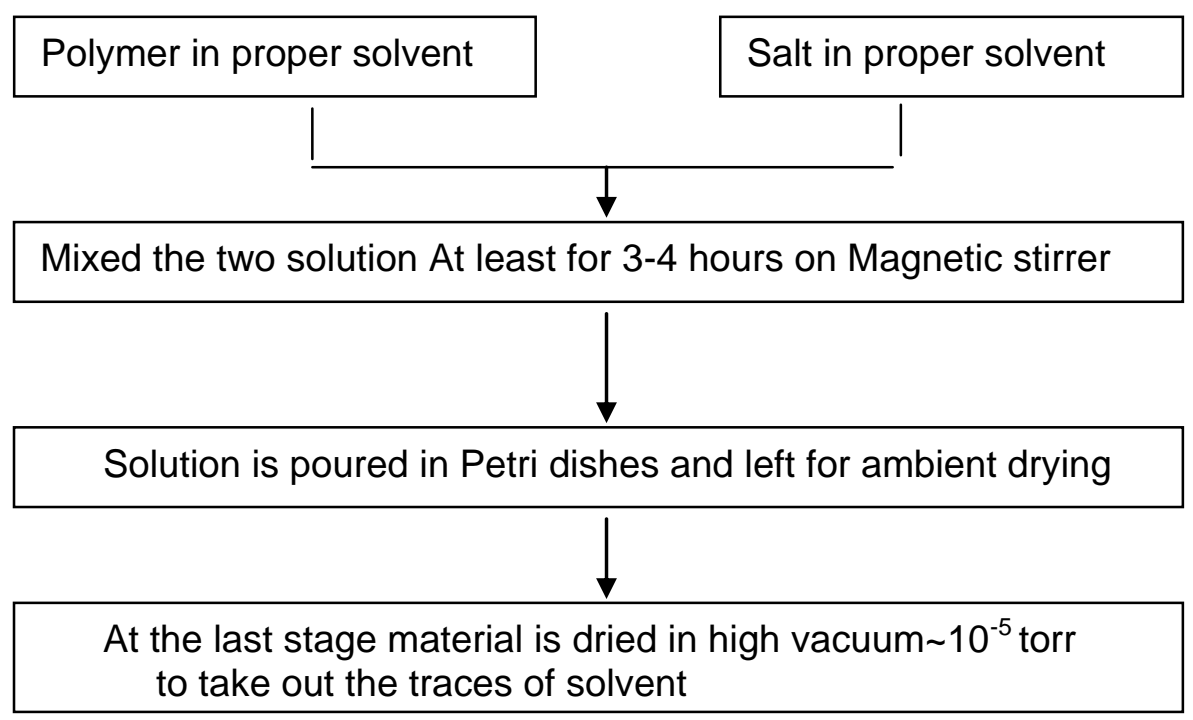

Fig. 1. A standard method of preparing SPE.

The increase of salt concentration is limited by triplet formation which results in decreased number of mobile charge carriers and lower mobility. Generally the conductivity vs wt\% of added salt curve shows two maxima as shown in Fig. 2.

Tab. 2. Examples of modified Polymer electrolytes. 


\begin{tabular}{|c|c|c|c|c|}
\hline S.No. & Electrolyte & $\sigma \mathrm{S} / \mathrm{cm}$ & Temp ${ }^{\circ} \mathrm{C}$ & Ref. \\
\hline 1 & $\mathrm{PEO}+\mathrm{PPO}+\mathrm{PC}+\mathrm{LiClO}_{4}$ & $2 \times 10^{-3}$ & 25 & 34 \\
\hline 2 & Ps-b-PVBPA+PPO & $1.48 \times 10^{-3}$ & 25 & 35 \\
\hline 3 & P(VDF-co-CTFE)-g-PSSA & $6.8 \times 10^{-2}$ & R.T. & 36 \\
\hline 4 & $(\mathrm{PE}-\mathrm{b}-\mathrm{PEO})+\mathrm{LiClO}_{4}$ & $10^{-3}$ & 100 & 37 \\
\hline 5 & PEO-PPO-PEO+(ionically active) $\mathrm{SiO}_{2}$ & $8.0 \times 10^{-5}$ & 30 & 38 \\
\hline 6 & $\begin{array}{l}\text { Polymer/clay nanocomposite } \\
\text { (Montmorillonite)MMT clay }\end{array}$ & $2.5 \times 10^{-3}$ & R.T & 39 \\
\hline \multirow[t]{2}{*}{7} & $(90 \% \text { PEO- } 10 \% \text { Poly- } 4)_{10}$ & $7.5 \times 10^{-4}$ & 80 & 40 \\
\hline & $\begin{array}{l}90 \% \text { PEO-10(poly- } \\
4 / \mathrm{TCNQ})_{10}\left(\mathrm{LiN}\left(\mathrm{CF}_{3} \mathrm{SO}_{2}\right)_{2}\right)\end{array}$ & $1.6 \times 10^{-3}$ & & \\
\hline 8 & $\mathrm{P}(\mathrm{VdF}-\mathrm{HFP}) / \mathrm{P}(\mathrm{EO}-\mathrm{EC})+\mathrm{TiO}_{2}$ & $5.1 \times 10^{-5}$ & 25 & 41 \\
\hline 9 & Poly(acrylonitrile-butylacrylate) & $3.0 \times 10^{-3}$ & R.T. & 42 \\
\hline 10 & $\begin{array}{l}\text { Poly(4-vinylphenol-co- } \\
\text { methylmathacrylate)\&Polaroid®B- } \\
\text { 82acrylic copolymer } \\
\text { resin+AMPS.HEMA.PEGDMA,BPO }\end{array}$ & $3.0 \times 10^{-2}$ & 70 & 43 \\
\hline 11 & PEGMEMA-AN-MMA+LiCIO & $10^{-4}$ & R.T. & 44 \\
\hline 12 & $\begin{array}{l}\text { N-Butyl-N-methyl morpholinium } \\
\text { bis(trifluoromethane sulfonyl)imide- } \\
\text { PVdF(HFP)+PC }\end{array}$ & $10^{-2}$ & 60 & 45 \\
\hline 13 & $(P M M A)_{x}-b-\left(P_{n}-E G M A\right)_{y}+$ Li salt & $4.8 \times 10^{-5}$ & 90 & 46 \\
\hline 14 & Poly(AN-co-GMA-IDA)+PC & $2.17 \times 10^{-3}$ & 30 & 47 \\
\hline 15 & P(VDF-co-CTFE)-g-PSSA & $\begin{array}{l}7.4 \times 10^{-2}- \\
6.8 \times 10^{-2}\end{array}$ & R.T. & 48 \\
\hline 16 & $\begin{array}{l}\text { Poly(methyl siloxzne)with } \\
\text { pendantPEO chain }\end{array}$ & $1.01 \times 10^{-4}$ & 30 & 49 \\
\hline 17 & $\mathrm{P}$ (EO/EM)-22+StarEO-OMe+LiTFSI & $10^{-4}$ & 10 & 50 \\
\hline 18 & $1 \mathrm{M} \mathrm{LITFSI}$ in $\mathrm{y}-\mathrm{BL}+\mathrm{hCPEO}$ & $10^{-2.5}$ & 20 & 51 \\
\hline 19 & PVdF-HFP/EC/PC/LiPF 6 & $>10-^{3}$ & -20 to R.T. & 52 \\
\hline 20 & PVdF-co-HFP-PMMA & $10.23 \times 10^{-3}$ & R.T. & 53 \\
\hline 21 & $\mathrm{P}(\mathrm{AN}-\mathrm{MMA})$ & $1.25 \times 10^{3}$ & R.T. & 54 \\
\hline 22 & $\begin{array}{l}\mathrm{P}(\mathrm{VdF}-\mathrm{HFP}) / \mathrm{SiO}_{2} / \mathrm{LiTFSI} \text { in BMITFSI } \\
(\mathrm{IL})\end{array}$ & $4.3 \times 10^{-3}$ & 25 & 55 \\
\hline 23 & PYR $_{14}$ TFSI(IL)+LiTFSI+PEGDME & $4.2 \times 10^{-3}$ & 29 & 56 \\
\hline 24 & (IL)[BMIM][TFSI]/CsHSO 4 & $10^{-3}-2 \times 10^{-2}$ & $80-180$ & 57 \\
\hline 25 & $\begin{array}{l}\text { PMMA+PEO8:LiClO4+PC/EC+SrBi4T } \\
\text { i4O15 }\end{array}$ & $.72 \times 10^{-5}$ & 21 & 58 \\
\hline 26 & $\begin{array}{l}(\mathrm{PEO})_{8} \mathrm{LiClO}_{4}+.05 \% \text { carboxylic acid } \\
\text { composite }+\mathrm{Al}_{2} \mathrm{O}_{3}\end{array}$ & $3.81 \times 10^{-4}$ & 20 & 59 \\
\hline
\end{tabular}

Nature of salt, i.e. size of cation and anion, salt's lattice energy, organic/ inorganic salt etc, plays very important role in polymer electrolyte's behavior determination. It has been found that larger anion results in amorphous matrix and provides path for cation movement hence a large conductivity is found in these system. Salts resulting in good conductivity and in use now days are summarized in Table 3 [60-68]. Many detailed reviews $[69,70,71,72]$ are available in the literature discussing different 
approaches to increase the performance of PEO based electrolytes hence authors are not discussing this in detail.

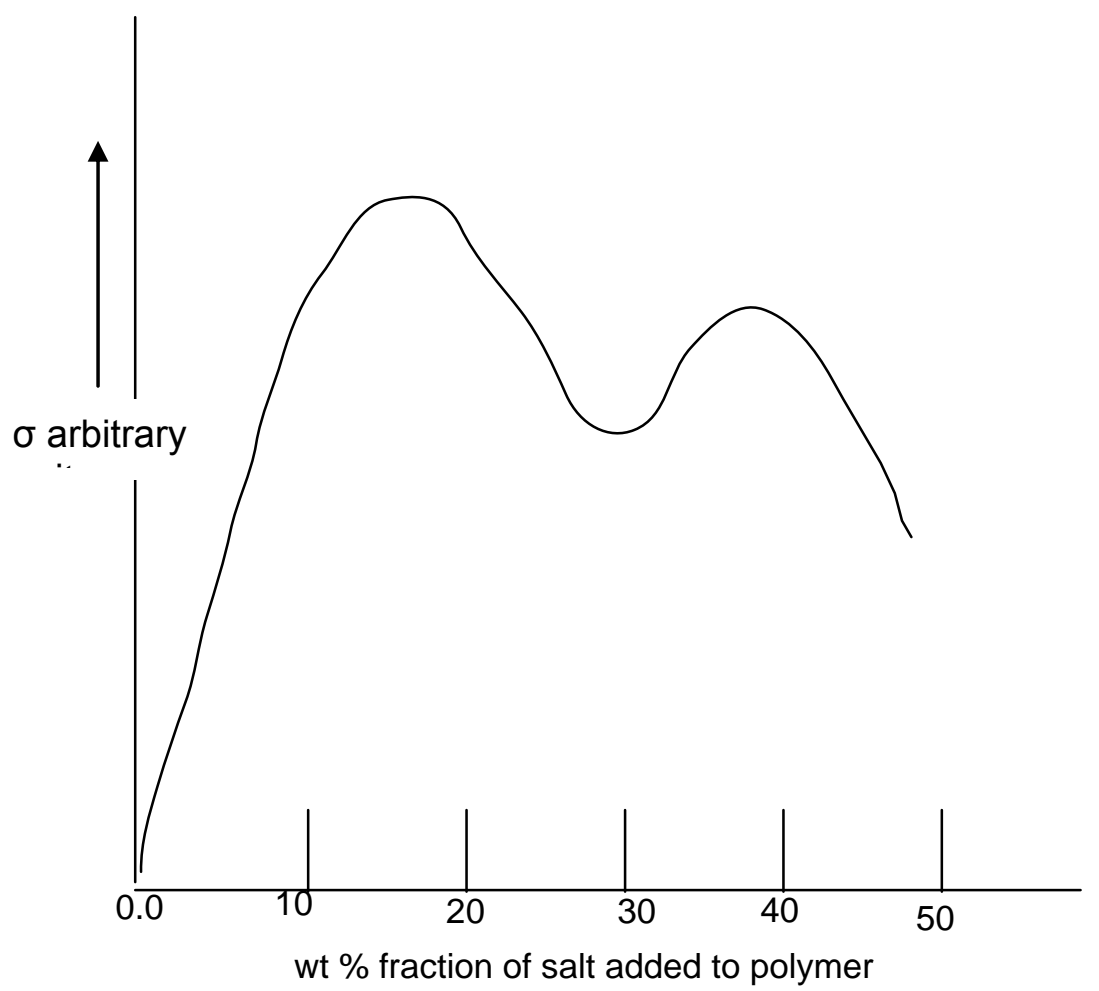

Fig. 2. General trend of conductivity dependence on salt concentration added to the system.

Tab. 3. Some typical salts resulting in high conducting network with polymer.

\begin{tabular}{rcccc}
\hline S.No. & Salts & $\begin{array}{c}\text { Conductivity } \\
\text { S/cm }\end{array}$ & Temp. ${ }^{0} \mathrm{C}$ & Ref. \\
\hline 1 & $\mathrm{LiClO}_{4}$ & $\sim 4.5 \times 10^{-5}$ & R.T. & 60 \\
2 & $\mathrm{LiClO}_{4}$ & $5.8 \times 10^{-7}$ & 90 & 61 \\
3 & $\mathrm{LiClO}_{4}$ & $1.04 \times 10^{-2}$ & R.T. & 62 \\
4 & $\mathrm{LiClO}_{4}$ & $3.7 \times 10^{-7}$ & R.T. & 63 \\
5 & $\mathrm{LiPF}_{6}, \mathrm{LiBF}_{4}$ & $3.1 \times 10^{-3}$ & R.T. & 64 \\
6 & $\mathrm{LiTFSI}$ & $7 \times 10^{-3}$ & 25 & 60 \\
7 & $\mathrm{LiTFSI}$ & $.11-.61 \times 10^{-3}$ & 20 & 65 \\
8 & $\mathrm{LiTFSI}$ & $2.3 \times 10^{-3}$ & 25 & 66 \\
9 & $\mathrm{LiTFSI}$ & $10^{-4}$ & 30 & 67 \\
10 & Nal & $1.5 \times 10^{-5}$ & 30 & 68 \\
\hline
\end{tabular}

\section{Gelled Polymer Electrolytes}

Improvement in SPEs conductivity and modification of the mechanical properties is brought by i) addition of low molecular weight polymers/ plasticizer properties etc. ii) mixing physically or chemically two or more than two polymers together.

Tab. 4. Gelled polymer electrolyte systems. 


\begin{tabular}{|c|c|c|c|c|}
\hline S.No & Electrolyte & Conductivity Scm ${ }^{-1}$ & Temp $^{\circ} \mathrm{C}$ & Ref \\
\hline 1 & PMMA-EC/PC/DMC-Nal// ${ }_{2}$ & $6.89 \times 10^{-9}$ & 25 & 75 \\
\hline 2 & $\begin{array}{l}\text { PEGDE+DEGBA+ } \omega \text {-diamino } \\
\text { poly(propylene oxide)+Li }\end{array}$ & $2 \times 10^{-3}$ & 25 & 76 \\
\hline 3 & Poly $($ AN-co-PEGMEM $)+P C+\mathrm{LiClO}_{4}$ & $2.51 \times 10^{-3}$ & $30-90$ & 77 \\
\hline 4 & $\mathrm{EG} / \mathrm{CA}: \mathrm{LiClO}_{4}$ & $2.3 \times 10^{-4}$ & R.T. & 78 \\
\hline 5 & $(\mathrm{PVdF}-\mathrm{HFP})+\mathrm{EC}+\mathrm{DEC}+\mathrm{Sb}_{2} \mathrm{O}_{3}+\mathrm{LiDFOB}$ & $2.98 \times 10^{-4}$ & R.T. & 79 \\
\hline 6 & PVdF+PEMA & $1.5 \times 10^{-4}$ & 28 & 80 \\
\hline 7 & PEMEIml+ $\left.\right|_{2}+$ polyacrylonitrile+EC+PC & $10^{-3}$ & R.T. & 81 \\
\hline 8 & $\mathrm{PEO}+\mathrm{LiClO}_{4}+\mathrm{LiOH}+\mathrm{Li}_{2} \mathrm{SO}_{4}+\mathrm{DMF}$ & $10^{-4}$ & R.T. & 82 \\
\hline 9 & $\mathrm{PEOMA}+\mathrm{BMIPF}_{6}+\mathrm{PC} / \mathrm{EC}+\mathrm{LiPF}_{6}$ & $9.4 \times 10^{-4}$ & 25 & 83 \\
\hline 10 & Poly(acrylonitrile-butyl acrylate) & $3 \times 10^{-3}$ & R.T. & 84 \\
\hline 11 & Polyoxyalkylene glycol acrylate & $6.2 \times 10^{-3}$ & R.T. & 85 \\
\hline 12 & [LPEI-HCl]+malonaldehyde in aq. $\mathrm{H}_{3} \mathrm{PO}_{4}$ & $1.1 \times 10^{-2}$ & 150 & 86 \\
\hline 13 & $\begin{array}{l}\text { N-Butyl-N-methylmorpholinium } \\
\text { bis(trifluoromethane sulfonyl) imide- } \\
\text { PVDF(HFP)+PC }\end{array}$ & ca. $10^{-2}$ & 60 & 87 \\
\hline 14 & MMA+LiAMPS & $.2 \leq \sigma \leq .8 \times 10^{-3}$ & $20 \pm 1$ & 88 \\
\hline 15 & TMPTA\&TMPETA & $5 \times 10^{-3}-6 \times 10^{-3}$ & 20 & 89 \\
\hline 16 & $\mathrm{PEGDA} / \mathrm{LiCF}_{3} \mathrm{SO}_{3} / \mathrm{Mg}-\mathrm{Al}$ LDH-2 & $1.6 \times 10^{-3}$ & 25 & 90 \\
\hline 17 & $\mathrm{Mg}\left(\mathrm{ClO}_{4}\right)_{2}+\mathrm{EC} / \mathrm{PC}+\mathrm{PAN}$ & $3.2 \times 10^{-3}$ & R.T. & 91 \\
\hline 18 & PEGDA/PVdF/F127(PEO-PPO-PEO) & $1.895 \times 10^{-3}$ & R.T. & 92 \\
\hline 19 & $\begin{array}{l}\text { Poly(AAc-DEA- } \\
\text { AAm)/PC/DME/DOL/LiClO }\end{array}$ & $10^{-3}-10^{-4}$ & -30 & 93 \\
\hline 20 & $\begin{array}{l}\mathrm{Li}-\mathrm{SiO}_{2}+\mathrm{DMSO}, \mathrm{DMA} / \mathrm{EC} \\
+\left[\mathrm{C}_{3} \mathrm{mpyn}\right]\left[\mathrm{NTf}_{2}\right](\mathrm{IL})\end{array}$ & $10^{-3}$ & R.T. & 94 \\
\hline 21 & PEMEIml//2/PAN/EC+PC & $10^{-3}$ & R.T. & 95 \\
\hline 22 & $\mathrm{P}(\mathrm{AN}-\mathrm{co}-\mathrm{BuA}) \mathrm{PVCblend}, \mathrm{EC}+\mathrm{DEC}+\mathrm{LiPF}_{6}$ & $>1.5 \times 10^{-3}$ & R.T. & 96 \\
\hline 23 & PEO/PPO diamines/LiClO $/ 4$ PC & $2 \times 10^{-3}$ & 25 & 97 \\
\hline 24 & $\mathrm{PAN} / \mathrm{EC} / \mathrm{PC} / \mathrm{Pr}_{4} \mathrm{~N}^{+} \mathrm{I}^{-}$ & $2.9 \times 10^{-1}$ & R.T. & 98 \\
\hline 25 & $\begin{array}{l}\text { PVdF-HFP/PEG/PEGDMA/LiPF/EC- } \\
\text { DEC }\end{array}$ & $1 \times 10^{-3}$ & R.T. & 99 \\
\hline 26 & PVC-PAN-LiCIO 4 -EC-TiO 2 & $4.46 \times 10^{-3}$ & R.T. & 100 \\
\hline 27 & PVA/PAMPS/PEG 400 & $2 \times 10^{-3}-8.3 \times 10^{-3}$ & $\sim 25$ & 101 \\
\hline 28 & $\begin{array}{l}\text { Liquid oligomeric PEGDME trapped in } \\
\text { crosslinked PMMA }\end{array}$ & $4.3 \times 10^{-4}$ & R.T. & 102 \\
\hline 29 & $\mathrm{PEO}-\mathrm{PMA}+\mathrm{Mg}\left[\left(\mathrm{CF}_{3} \mathrm{SO}_{2}\right)_{2} \mathrm{~N}\right]_{2}$ & $1.1 \times 10^{-4}$ & 20 & 103 \\
\hline 30 & PVA-PAMPS-PEGBCME & $9.5 \times 10^{-2}$ & 25 & 104 \\
\hline 31 & $\mathrm{PVC} / \mathrm{PAN} / \mathrm{EC} / \mathrm{LiClO}_{4} / \mathrm{PC}$ & $7.57 \times 10^{-5}$ & R.T. & 105 \\
\hline 32 & PVC-PEMA-PC-LiBF 4 & $6.72 \times 10^{-3}$ & 28 & 106 \\
\hline 33 & PVdF-PDPA-CFM-1MLiCIO 4 -PC & $3.6 \times 10^{-3}$ & 25 & 107 \\
\hline
\end{tabular}

These polymer electrolytes have liquid electrolytes trapped in polymer matrix. These materials have received great attention because of the high conductivity, high energy density, better possibility of geometrical variation and safety [73]. The matrix varies from homopolymers, copolymers, polymer blends to modified polymers. They consist of liquid electrolytes of low molecular PEG/PEO/ propylene carbonate (PC)/ ethylene carbonate $(E C) /$ diethylene carbonate (DEC) etc mixed with suitable salts. Polymer hosts like PMMA, poly(acrylonitrile) [74], poly(vinylidene fluoride)-fluoropropylene, poly(vinyilidene fluoride)-hexa-fluoropropylene copolymer matrix are found suitable to immobilize these salt solutions and transfer them in gel polymer electrolytes. 
(a)

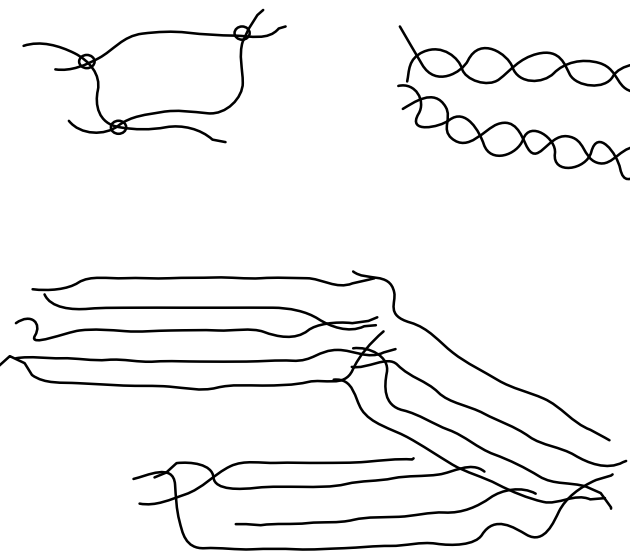

(c) (b)

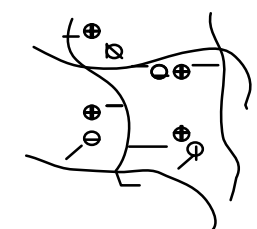

(d)

( $\bigcirc$-------Chemical bonding points)

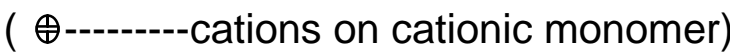

( $\theta$--------anions on anionic monomers)

Fig. 3. Different Gelling States (a) chemically gelled (b), (c) \& (d) physically gelled networks (Junction zones, Fringe micelles respectively \& ionically gelled materials respectively)

Table 4 [75-107] shows some examples of gel polymer electrolytes along with their conductivity. These polymer electrolytes have better conductivity and less effected by the temperature variations but poor mechanical properties when compared to the Dry SPE. They are developed in different ways, Fig. 3 shows the different possible gelling structures. a) Gelling by physical cross linking (PAN, PVDF etc): Such type of crosslinked gel networks are also called the 'entanglement network. These entanglements can be of many types i) 'junction zones' where the polymeric chains interact over a portion of their length (Fig. 3b) and the ii) 'fringe micelles' where the chains align in some regions to form small crystallites (Fig. 3c) iii) ionic interaction which is caused by the cations and anions available on the polymers (Fig. 3d). These ions result in high density electrostatic interaction giving a stable structure to matrix etc. The ionic interaction is very powerful and gives most stable physically cross-linked gel. Physically crossed linked gelled polymer electrolyte tends to swell and structure changes with time and system leaks also. Change in environment change number of junction points b) gelling by chemical cross linking: [example P(VDF-HFP) etc] Here polymer chains undergo covalent bonding by means of a chemical reaction (Fig. 3a). Covalent cross-linking leads to the formation of stable/ irreversible gels. In such gels, the number of contact points/junction-points is formed due to chemical bonding. The number of junctions do not change with the conditions such as temperature, concentration, or stress hence they are more stable systems. But their conductivity is less in comparison to physically cross-linked gels. Fig. 4 shows the effect of temperature on the physically and chemically cross linked gels. The gel preparation process has a wide spectrum. It varies from solvent based preparation in presence of salt, preparation of electrospun membrane, preparation of separate membrane by chemical process and then dipping them in liquid electrolytes to absorb the 
electrolytes in pores etc. Some typical latest reports of the field are given below to let the readers enjoy the flavor of each one.

(a)

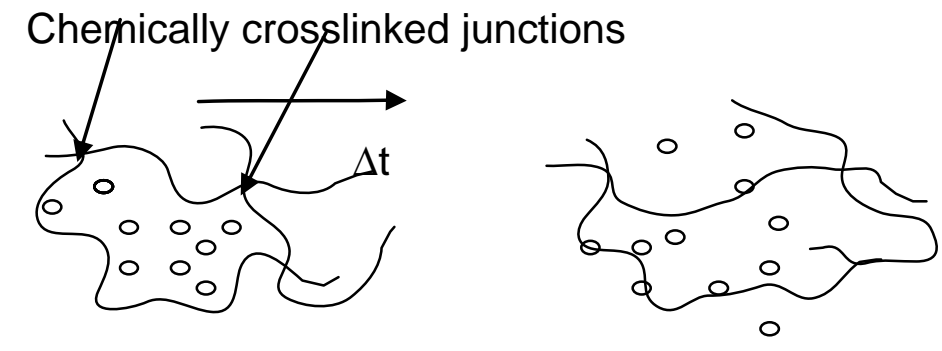

(b)
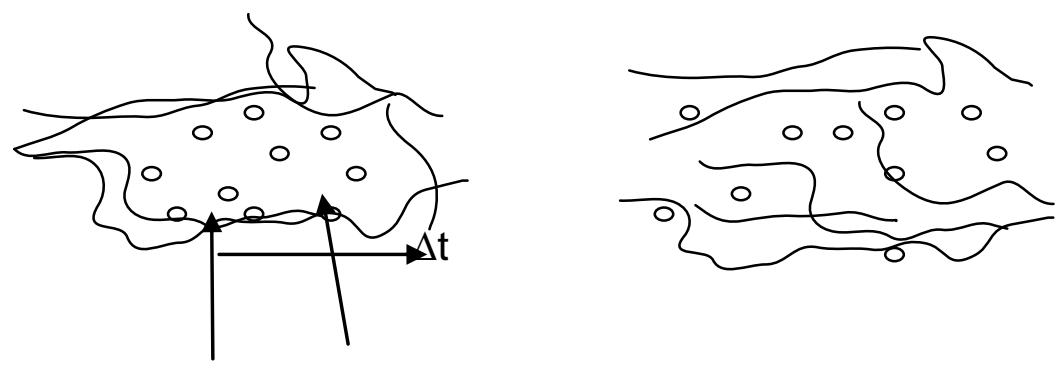

Physically entangled junctions

Electrolyte's molecules

Polymer chains making polymer network

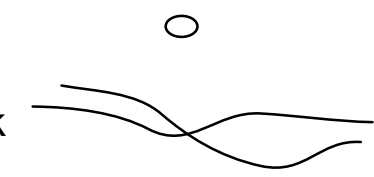

Fig. 4. Effect of Temperature on chemically cross linked gels (a) and physically cross linked gels (b).

Teng and his co-workers [108] have tried to reduce the crystallinity of PEO by crosslinking it with poly(propylene oxide) and then the membrane is soaked in liquid electrolytes $\left(\mathrm{PC}+\mathrm{LiClO}_{4}\right)$. The conductivity of the gelled electrolyte was $\sim 2 \times 10^{-3} \mathrm{Scm}^{-1}$ at room temperature (RT) and the material was having a wide electrochemical window. They also fabricated an electric double layer capacitor using prepared electrolyte; results were encouraging. Vandrack et al [109] has reported chemically synthesized gel. They used PMMA as well as its monomer MMA to accommodate $\mathrm{PC}+\mathrm{Li} / \mathrm{Na}$ electrolyte in the system. Ionic conductivity was $\sim 10^{-4} \mathrm{Scm}^{-1}$. Gel electrolytes can be formed by making suitable polymer membrane and then dipping them in electrolyte solution. Kim et al [110] has followed this path. Initially they prepared a membrane of PEGDA/PVDF and F127 (F127 has mole ratio EO/PO/EO = $106 / 70 / 106)$ by solution casting and then dipped it in PC+EC+salt solution. Extra liquid electrolyte stuck on the surface was removed by filter paper before using the electrolyte. In this system F127 found to play double role i) plasticizer and ii) as surfactant. Porosity and pore size of the membrane were dependent upon PEGDA to F127 ratio. This ratio affected the mechanical strength as well as electrolyte intake. Electrochemical window of the system was very good $\sim 4.5 \mathrm{~V}$ and conductivity of the order $\sim 10^{-3} \mathrm{Scm}^{-1}$. Ionically cross linked membranes are more stable hence scientists are getting interested in it. To develop ionically cross linked gel membrane PADA, Yang et al [111] used the radical copolymerization procedure to cross link cationic and anionic monomers. They used acrylic acid, N,N diethylamino ethyl methacrylate and acrylamide as initial materials to produce PADA. Material was thermally stable and had wide electrochemical window. Conductivity of the system depends upon 
cation to anion monomer ratio. Yamamoto and his group [33] reported a stable and safe 4.4V Li polymer battery having PVDF/EC/PC/LiPF 6 (mole ratio 7/43/43/7). Electrolyte's conductivity and its temperature dependence were found to be comparable to liquid electrolyte EC/DEC/ $\mathrm{LiPF}_{6}(27 / 63 / 10$ mole \%). Gel based 4.4.V cell performance was much better than that of liquid electrolyte. Gel electrolyte cell nicely handled the challenges of overcharging and cathode degradation. Ionic liquids and zwitterions are also used to produce gel electrolytes. As they are latest and have fascinating properties we will discuss them separately. S. Rajendrana \& P Sivakumar [112] in their study have shown that PVdF+HFP system mixed with $\mathrm{LiClO}_{4}$ and $\mathrm{PC} / \mathrm{EC}$ as plasticizer has ac conductivity $\sim 10^{-3} \mathrm{Scm}^{-1}$ and thermal stability was found up to $250{ }^{\circ} \mathrm{C}$. Crystallinity, porosity and pore size were studied by SEM, TG/DTA. These parameters are sensitive to PVdF and EC/PC. A co-polymer system made up of poly(ethylene glycol-methyl-methoxy (PEGMEM) and acrtyonitrile is reported by Yu-Hao Liang and his co-worker [113]. Gelled polymer is developed by mixing 'LiCLO 4 in PC' and prepared co-polymer. Conductivity of the system was $\sim 2.5 \times 10^{-3}$ $\mathrm{Scm}^{-1}$. Segments (C-C-O and $\mathrm{C} \equiv \mathrm{N}$ ) of PEGMEM is found to promote the dissociation of lithium salt. Choi and co-worker [114] has shown that if porous poly(vinylidene flupro-co-hexaflouro propylene) membrane is dipped in electrolyte solution $\left(\mathrm{EC} / \mathrm{DMC}+\mathrm{LiClO}_{4}\right)$ containing organic additives, the resulting system can be used as electrolyte in $\mathrm{Li}$ cell. The presence of organic additives gives different cell performance as they are electrochemically oxidized to form conductive polymer film on the electrode at high potential. The addition of small amount of suitable polymerizable additives has reduced the interfacial resistance of the cell during cycling resulting in low capacity fading and increased high rate performance. Thermal stability of these cells was also increased due to additives. All these parameters depends also upon the type of additive (namely: thiophene, 3,4-ethylene dioxythiophene and biphenyl). Above discussed examples are only some typical and latest examples readers are suggested to go through reviews $[115,116,117,118]$ to get a detailed knowledge of the field.

\section{Composite Polymer Electrolytes}

In literature author could not find a very clear cut definition of composite polymer electrolytes. It is used in different reference at different time [119, 120]. Authors are using it to define a system where nano/micron particles are used to modify the polymer electrolytes. In this modification process small inert particles having high dielectric constant are mixed in polymeric systems. This results in new type of the system which has better properties in comparison to the original electrolyte. Literature shows that sorbents affect the properties of electrolytes to a very great limit. It modifies mechanical and electrical/optical transport properties. Particle size plays an important role. Fillers are basically oxides like $\mathrm{TiO}_{2}, \mathrm{SiO}_{2}, \mathrm{Al}_{2} \mathrm{O}_{3}, \mathrm{BaTiO}_{3}$, $\mathrm{PbTiO}_{3}$ etc. Ferroelectric fillers are always better and result in stable systems in comparison to ordinary oxide fillers. Conductivity changes can be associated with the increase in number of charge carriers due to dissociation of salt in the presence of the high dielectric material. It has also been proposed that addition of fillers i) increases amorphous part of the polymer, ii) provides a new path to charge carriers through polymer ceramic interaction and iii) behaves as nucleation sites for small crystallites formation etc. Added ceramic does not undergo any kind of chemical changes or chemical bonding with salt or polymer. In Lithium trifluoromethane sulfonate: polyethylene oxide (PEO) polymer electrolytes modified by 1,1,3,3,5,5meso-hexaphenyl-2,2,4,4,6,6-mesohexamethyl-6-PYRROLE(C6P) doped with $\mathrm{SiO}_{2}$ 
system. Major and his co-workers [121] has shown that fillers play an important role by providing inter-facial ion conduction path. $t_{+}$strongly depends upon percent content of $\mathrm{C} 6 \mathrm{P}$ and $\mathrm{SiO}_{2}$. It varies from 0.54 for $\mathrm{LiCF}_{3} \mathrm{SO}_{3}: \mathrm{P}(\mathrm{EO})_{9}$ to 0.82 for $\mathrm{LiCF}_{3} \mathrm{SO}_{3}: \mathrm{P}(\mathrm{EO})_{9}:(\mathrm{C} 6 \mathrm{P}) 0.125+6 \%$ (wt.) $\mathrm{SiO}_{2}$. Rajendran and his co-worker added $\mathrm{TiO}_{2}$ particles in PVC/PAN blend having 'LiClO 4 in EC'. System has shown nearly 100 times jump in ac conductivity. Thermal stability of the system also improved [100]. Vondrak et al [109] used nano particle sorbents $\left(\mathrm{Al}_{2} \mathrm{O}_{3}\right)$ in PMMA and ' $\mathrm{NaClO} / \mathrm{LiClO}_{4}$ in PC'. Material's mechanical, electrical as well as optical properties changed a lot. Transparency of the system is $\mathrm{Al}_{2} \mathrm{O}_{3}$ concentration dependent, which makes it suitable for electrochromic devices. Stolarska et al, [122] have used the PVDF+HFP copolymer as a membrane and $\mathrm{Al}_{2} \mathrm{O}_{3} / \mathrm{TiO}_{2}$ as fillers and found that electrolyte's crystallinity decreased with the addition of sorbents $\left(\mathrm{Al}_{2} \mathrm{O}_{3} / \mathrm{TiO}_{2}\right.$ modified as well as pure) consequently conductivity increased by an order. Presence of sorbents decreased the electrolyte/electrode interfacial resistance also.

\section{Ionic Liquid/ Zwitterionic Materials}

In 1990 Sony first time commercialized the Li+ ion battery. Since then tremendous efforts have been made to improve its current, voltage, working temperature range etc. Presently used $\mathrm{Li}+\mathrm{ion}$ batteries consist of ethyl carbonate (EC), dimethyl carbonate (DMC) diethyl carbonate (DEC) with lithium hexafluorophosphate. The charging/ discharging characteristics of these batteries are interesting and hence manufacturers are attracted to their commercial production. But their thermal instability and flammability are the biggest problem. Organic solvents used in these materials are volatile and flammable which resulted in safety hazards in $\mathrm{Li} / \mathrm{Li}$ ion batteries [123]. The working temperature range of such materials is $-20{ }^{\circ} \mathrm{C}$ to room temperature. Scientists are trying to increase it up to $40{ }^{\circ} \mathrm{C}$. Methyl Acetate (MA) \& ethyl propionate $(E P)$ and ethyl butyrate $(E B)$ were tried but the desired success is still awaited. Under electrochemical applications, many times, the starting material changed after first cycle due to ester exchange type of chemical changes. Hence the material does not remain same consequently their device performance is not well defined. Such type of shortcomings keep the area of electrolyte development still an open one demanding extensive work. Now scientists have started looking for solvents which are having i) low viscosity ii) large polarity iii) low melting and high boiling point etc along with non-volatility thermal stability non-flammability, extremely high ionic conductivity. As an alternative solvent the 'Ionic Liquids (IL)/ Molten Salts' are collecting keen interest as novel solvents as they possess all these unique characteristics. Because of their safety features these solvents are called Green Solvents [124,125,126,127] and have a wide application range.

Most of the electrolytes studied are generally a mixture of salt and some solvent (liquid or polymeric). Such systems have charged particle along with their counterparts and neutral particles also. It has been thought that if the charge content is increased then the conductivity will certainly increase. To make it possible salts were given heat energy to counter balance their lattice energy so that the salt itself will be in a melted form or let us say they are liquefied, They are 'Molten Salts' or 'Ionic Liquid'. Since the 'Molten Salts' or 'Ionic Liquid' are prepared by supply of heat energy their temperature application range is limited and high as well. To bring the temperature range down to ambient mixing of two or more salts resulting in a eutectic were tried and success is achieved. The salts available in molten form at ambient were called Room Temperature Liquids (RTL). Physiochemically high temperature 
and low temperature 'Ionic Liquid' are same the only difference lies in their application. Generally salts having melting point up to $100{ }^{\circ} \mathrm{C}$ are defined as RTL. Initially Complex of chloroaluminate type molten salts were prepared (example: butylpyridinium chloride $+\mathrm{AlCl}_{3}+$ poly(butylpyridinium chloride) which showed conductivity $\sim 10^{-3} \mathrm{Scm}^{-1}$ in film form [128] but these materials were badly affected by humidity. Later it has been recognized that [129,130,131] imidazolium cation and organic anions can be combined to get stable molten salts. After that lots of molten salts/lonic liquids (Acetate IL, Amides \& Imides, Borates, Cynates, halogenides, Phosphates \& phosphinates, Sulfates \& Sulfonates IL etc $[132,133,134])$ were synthesized for different applications. When these ionic liquids were tried as solvents for electrolytes their ion rich nature became a problem as the ions of the matrix has started moving under applied potential and \% of target ion conductivity decreases. That means lack of selectivity in target ion transport is a crucial problem with these materials for device application. Ionic Liquids are organic materials. Hence Polymerization or Modification of their structure is an easy process. This is the greatest advantage of IL/Molten salts. Hence a series of New Salts in which cationic unit is covalently tethered with anionic one has been developed. They have been given a new name Zwitterionic Salts. They can be polymerized as well. These Zwitterionic Polymers are technologically very important. Such materials have been first time electrochemically used by Ohno and Co-workers [135]. Zwitterionic polymers are macromolecules comprising of positively and negatively charged groups As both cation and anion are in intra-molecular form, they cannot migrate with the potential gradient (this is its advantage in comparison to IL/Molten salts). Very high dipole moment $(\mu \sim 23 D$ ) extends the characteristic of unique polar host matrix. When complexed with salt, the counter ion is fixed on the main chain of the polymer resulting in single ion conducting polymer. It possesses a strong salvation power towards a variety of polar or ionic guest species. Using those excellent matrices is produced, having high ionic conductivity. Moreover the gel nature facilitates the controlled fabrication. Their stoichiometric blends with alkali metal salts of low lattice energy produce ionically conducting amorphous systems.

These materials are resulting in a great success. They are used with traditional polymer matrix as well as with different and new matrices. Following is a short review of this emerging field. Ionic liquids are known as green solvents because of their low volatility and hardly flammable properties reducing the side effects on worker as well as users of electrochemical devices made up of these materials. The ILs came as a great rescue to electrolytes because after all efforts the conductivity of dry polymer electrolytes could be increased beyond $10^{-3}$ to $10^{-4} \mathrm{Scm}^{-1}$ limit. At first attempt electrochemists tried to use IL only as solvent and added salts to it but strong columbic interaction between ionically rich IL and salt resulted in increased viscosity and hence decreased conductivity. These systems were not satisfactory at many other fronts $[136,137]$ also i) being ionically rich the ions of the IL itself stared moving ii) device rate compatibility (when compared with non-aqueous electrolytes) is poor iii) A non-active layer is formed at electrode which is harmful for battery life and iv) ILs also suffer from poor wet-ability of separator. Hence a combination of less viscous organic solvent and other polymers along with IL are presently being tried. As discussed in Gel electrolytes PVDF+HFP are very good matrix for Gel preparation. Singh et al [138] have prepared 2,3-dimethyl-octylimidazolium tetrafluoroborate $\left(\mathrm{DMOImBF}_{4}\right) \mathrm{IL}$.It is used to prepare Gel Electrolyte using solution cast technique. IL, PVDF+HFP, $\mathrm{PC}$ and $\mathrm{NH}_{4} \mathrm{BF}_{4}$ were dissolved in acetonitrile and methanol. Materials were in film form having conductivity $\sim 10^{-4} \mathrm{Scm}^{-1}$ at $25{ }^{0} \mathrm{C}$. Thermal stability was found 
up to $200{ }^{\circ} \mathrm{C}$ but NMR has indicated that cation and anions both are mobile. Lab prepared 1-butyl-4-methylepyridinium bis (trifluoromethane sulphonyl) imide (BMPYTFSI) mixed in PEO + LiTFSI electrolyte system was reported by Yang and his co-workers [139]. At $40{ }^{0} \mathrm{C}$ conductivity was $\sim 6.9 \times 10^{-4} \mathrm{Scm}^{-1}$. $t_{L i}$ decreases with increasing IL's content but the Li ion conductivity increases with it. SEM result has indicated that morphology of the system became compact and smooth after addition of IL. Kern and his co-workers [140] used PEO based electrolyte mixed with the ionic liquid PYR14TFSI along with LiTFSI. They used photochemical cross-linking process. The conductivity is found to increase with the IL content. Anion conducting electrolyte is getting attention with possibility of their uses in dye sensitized solar cells. Many IL based gels are recently reported. Liu et al [141] have developed poly ionic liquid 1ethyl 3-(methacryloyloxy ethyl) immidazolium iodide [PEMEIm]. Material mixed with the $\mathrm{I}_{2}$, plasticizer and polyacronitrile is amorphous resulting in good room temperature conductivity $\sim 10^{-3} \mathrm{Scm}^{-1}$ and is stable up to $280^{\circ} \mathrm{C}$. The multi-functional Zwitterionic (having both an ester and a sulfonate groups) compounds have shown better properties in comparison to the simple alkyl and sulfonate groups containing zwitterions [142]. In its transport $\mathrm{Li}$ is found to interact with both the sulfonate and ester group in electrolyte consisting $1 \mathrm{M} \mathrm{LiPF6}$ in a mixture of EMC, DMC, EMC (1/1/1 by vol.) and a Zwitterionic compound (2.25 wt\%). In the presence of ester group decomposition of electrolyte at the electrode is reduced to a great extent. Zwitterionic material's side chains are very important [143] for viscosity and conductivity. It also increases cathodic stability. It depends upon the position of attached group. Zwitterionic compound bearing an ester group at the 1-position and a hydrogen or methyl group at the 2-position is inferior in comparison to the electrolytes containing a Zwitterionic imidazolium compound with an ester group at the 2-position. Such electrolytes exhibits improved cycling performance. The presence of an ester group at the 2-position significantly enhances the electrochemical stability of the Zwitterionic imidazolium compounds. It is proposed that this prevents the decomposition of the electrolyte on the electrode surface. Scientists are continuously working in the field to understand the interaction of Zwitterionic, salt and host matrix. FTIR studies carried out on (NBR; poly(acrylonitrile-co-1,4-butadiene)) and $\mathrm{Li}(\mathrm{CF} 3 \mathrm{SO} 2) 2 \mathrm{~N}$ (Li(Tf)2N) system with $9.2 \mathrm{wt} \%$ imidazolium-type zwitterion, have shown that $\mathrm{Li}+$ interaction with host reduces after addition of the Zwitterionic material. Such behavior is considered responsible for the improved conductivity as well as $\mathrm{Li}+$ ion transference number [144]. Taggougui [145] and co-workers mixed IL with organic solvent and studied mixtures of the IL hexyltrimethylammonium (N1116) bis(trifluoromethyl-sulfonyl)imide (NTf2) with the organic solvent mixture EC:DEC [40:60] in the presence of the lithium salt LiNTf2. The addition of IL increased the room temperature conductivity and it reached up to $0.5 \mathrm{Scm}^{-1}$ and remains in the same range even at low temperature $-20{ }^{\circ} \mathrm{C}$ and no vaporization is found upto $190{ }^{\circ} \mathrm{C}$. Half cell studies of these materials have been carried out and no lose of capacity and fading has been found during cycling.

\section{Summary}

The polymer electrolytes field is still wide open and the possibility of getting new and better systems needs more attention. No system is perfect and flawless whether it is PEO based conventional polymer electrolytes or latest IL based material. PEO based materials suffer from poor conduction and cation interaction with ether oxygen, organic solvent based gel electrolytes are prone to volatility and change their behavior with time. Composite materials are better when compared to these 
materials. IL based materials theoretically sound very nice because of low viscosity, large polarity, low melting and high boiling point etc along with non-volatility thermal stability non-flammability and extremely high ionic conductivity. But the practical results are not very encouraging as they suffer from low target ion transport, poor device rate capability etc. Zwitterionic salt/polymer seems to solve some of these problems but still need deep investigation.

Hence while working in the field of polymer electrolytes one should take care of other properties as well. Merely looking for better conductivity and mechanical properties will not solve the purpose. The understanding of nature of interaction between the salt and other materials present in the system, solid electrolyte/electrode interface, electrochemical window, working temperature window are a must to make a guide line for future.

\section{Acknowledgements}

The authors acknowledge DST New Delhi and Finance Officer BHU for financial support.

\section{References}

[1] Bruce, P. G. Solid State lonics 2008, 179, 752

[2] Patil, A.; Patil, V.; Dong, W. S.; Choi, Ji-Won.; Dong-Soo, Paik.; Yoon Seok, J. Materials Research Bulletin 2008, 43, 1913

[3] MacCallum, J.R.; Vincent, C.A. Polymer Electrolyte Reviews 1, Elsevier, London 1987.

[4] MacCallum, J.R.; Vincent, C.A. Polymer Electrolyte Reviews 2, Elsevier, London 1989.

[5] Armand, M.B.; Chabango, J.M.; Duclot, M. Second International Meeting on Solid Electrolytes, St.Andrews, Scotland, September 20-22,1978

[6] Robinson, E. K. (Bluefin Robotics Corporation)* January 07

[7] Polymer energy absorber for motor vehicles \& bumper system. United States Patent 7393030.

[8] Ito,Y.; Kanhori, K.; Miyauchi, K.; Kudo, T. J. Mater .Sci 1987, 22, 1845.

[9] Kelly, I.E.; Owen, J.R.; Steele, B.C.H. J. Power Sources 1985, 14, 13.

[10] Watanabe, M.; Kanba, M.; Nagaoka, K.; Shinohar, I. J. Appl. Electrochem. 1982, 27, 4191.

[11] Watanabe, M.; Kanba, M.; Nagakoa, K.; Shinohara, I. J. Polym. Sci. Polym.Phys.Ed. 1983, 21, 939

[12] Tsuchida, E.; Ohno, H.; Tsunemi, K. Electrochimica Acta 1983, 28, 591.

[13] Gray, F.M. Solid Polymer Electrolytes, VCH, New York, 1991.

[14] Park, C.W. et al. Journal of Power Sources 2007, 165, 450.

[15] Sivakumar, J. et al. Materials Letters 2006, 60, 3346.

[16] Nan, C.W.; Fan, L et al. Physical Review letters 2003, 19.

[17] Lin, C.W. et al. Journal of Power Sources 2005, 146, 397.

[18] Noda, K. et al. Electrochimica Acta 2004, 50, 243.

[19] Akoi,T. Electrochimica Acta 2004, 50, 301.

[20] Shen, Y.J. et al. Solid State Ionics 2004, 175, 747.

[21] Hu, L. et al. Solid State Ionics 2008, 179, 401.

[22] Bhide, A. et al. European Polymer Journal 2007, 43, 4253.

[23] Wang, X. et al. Journal of Polymer Science Part B - Polymer Physics 2001, 39, 2225 
[24] Bhargav, P.B. et al. lonics 2007, 13, 173.

[25] Zhou, Z.B. et al. Electrochemistry Communications 2007, 9, 1017.

[26] Rajendran, S. et al Physica B : Physics of condensed matter 2008, 403, 509.

[27] Watanabe, M.; Endo, T. et al. Journal of Power Sources 1999, 81-82, 786.

[28] Nishimoto, A.; Agehara, K. et al. Macromolecules 1999, 32, 1541

[29] Karan, N.K. et al. Solid State lonics 2008, 179, 689.

[30] Tsutsumi, H. et al. Solid State lonics 2006, 177, 2683.

[31] Wang, L.; Yang W. et al. Solid State lonics 2009, In Press

[32] Lascaud S, Perrier M, Vallee A, Besner S, Prud'homme J, Armand M Macromolecules 1994, 27, 7469.

[33] Yamamoto, T.; Hara,T.; Segawa, K.; Hondab, K.; Akashi, H. Journal of Power Sources 2007, 174, 1036.

[34] Tien, C. P. et al. Electrochimica Acta 2008, 53, 4505.

[35] Cho, C.G. et al. Journal of Membrane Science 2008, 308, 96.

[36] Kim, Y.W. et al. Journal of Membrane Science 2008, 313, 315.

[37] Guilherme, L.A. et al. Electrochimica Acta 2007, 53, 503.

[38] Wang, X. L. et al. Journal of Power Sources 2007, 171, 913.

[39] Wang, M. et al. Journal of Power Sources 2007, 170, 425.

[40] Itoh, T. et al. Journal of Power Sources 2006, 163, 252.

[41] Jeon, J. D. et al. Journal of Power Sources 2006, 162, 1304.

[42] Tian, Z. et al. Electrochimica Acta 2006, 52, 688.

[43] Pei, H. et al. Journal of Power Sources 2006, 160, 949.

[44] Wang, M. et al. Journal of Power Sources 2005, 139, 223.

[45] Kim, K. S. et al. Electrochimica Acta 2005, 50, 5673.

[46] Chang, S.M. et al. Synthetic Metals 2005, 154, 21.

[47] Liang, Y.H. et al. Journal of power Sources 2005, 148, 55.

[48] Kim, Y. W. et al. Journal of Membrane Science 2008, 313, 315.

[49] Jiang, H. et al. Journal of Power Sources 2006, 159, 673.

[50] Matoba, Y. et al. Journal of Power Sources 2004, 137, 284.

[51] Jannasch, P. et al. Solid State lonics 2004, 166, 417.

[52] Yamamoto, T. et al. Journal Of Power Sources 2007, 174, 1036.

[53] Sundaram, N.T.K. et al. Material Chemistry \& Physics 2008, 110, 11.

[54] Zhou, D.Y. et al. Journal of Power Sources 2008, 184, 477.

[55] Kim, J.K. et al. Journal of Power Sources 2008, 178, 815.

[56] Shin, J. H. et al. Journal Of Power Sources 2008, 177, 537.

[57] Kim, J. D. et al. Solid State Ionics 2008, 179, 1178.

[58] Shanmukaraj, D. et al. Journal of Physics \& Chemistry Of Solids 2008, 69, 243.

[59] Park, J.W. et al. Journal of Power Sources 2006, 160, 674.

[60] Patel, M. et al. Electrochimica Acta 2008, 54, 209.

[61] Rahman, M.Y.A. et al. Physica B:Condensed matter 2008, 403, 3414.

[62] Yang, Y.W.C. et al. Electrochimica Acta 2009, 54, 1218.

[63] Ahmad, A. et al. Physica B:Condensed Matter 2008, 403, 4128.

[64].Yoshimoto, N. et al. Journal of Power Sources 2008, 185, 1425.

[65] Zhao, J. et al. Journal of Power Sources 2008, 189, 359.

[66] Cheruvally, G. et al. Journal of Power Souces 2007, 172, 863.

[67] Masuda,Y. et al. Solid State lonics 2006, 177, 843.

[68] Nogueira, A. F. et al. Solid State Ionics 2001, 140, 327.

[69] Sundaram, N.T. K. Materials Chemistery \& Physics 2008, 110, 11. 
[70] Borkowska, R.; Laskowski, J.; Plocharski, J.; Pryzyluski,J.; Wieczorek, W. J Appl.Electrochem.1993, 23, 991.

[71] Wieczorek, W.; Florjancyzk, Z.; Stevens, J.R. Electrochimica Acta, 1995, 40, 2251.

[72] Quartarone, E.; Mustarelli P.; Magistris, A. Solid State lonics 1998,110, 1

[73] Zhao,D.Y. et al. Journal of Power Sources 2008, 184, 477

[74] Hayamizu, K.; Aihara, Y.; Arai, S.; Price, W. S. Electrochimica Acta, 2000, 45, 1313.

[75] Yang, H. X. et al. Materials Chemistry \& Physics 2008, 110, 38.

[76] Tien, C. P. et al. Electrochimica Acta 2008, 53, 4505

[77] Liang, Y. H. et al. Journal of Power Sources 2008, 176, 340.

[78] Tambelli, C. E. et al. Electrochimica Acta 2007, 53, 1535.

[79] Aravindan, V. et al. Solid State Sciences 2007, 9, 1069.

[80] Sivakumar, M. et al. European Polymer Journal 2007, 43, 4466.

[81] Feng, B. et al. European Polymer Journal 2007, 43, 2699.

[82] Mallick, I. B. et al. Journal of Power Sources 2006, 162, 797.

[83] Reiter, J. et al. Electrochimica Acta 2006, 52, 1398.

[84] Tian, Z. et al. Electrochimica Acta 2006, 52, 688.

[85] Kim, H. S. et al. Journal of Power Sources 2006, 159, 227.

[86] Glatzhofer, D.T. et al. Solid State Ionics 2005, 176, 2861.

[87] Kim, K. S. et al. Electrochimica Acta 2005, 50, 5673.

[88] Kalapala, S. et al. Journal of Power Sources 2005, 147, 256.

[89] Kim, S. L. et al. Electrochimica Acta 2004, 50, 317.

[90] Cho, M.S. et al. Electrochimica Acta 2004, 50, 331.

[91] Perera, K. et al. Materials Research Bulletin 2004, 39, 1745.

[92] Wang, Y. J. et al. Journal of Membrane Science 2008, 312, 76.

[93] Chen, W. et al. Electrochimica Acta 2007, 53, 2065.

[94] Sun, J. et al. Electrochimica Acta 2007, 52, 7083.

[95] Yu, B. et al. European Polymer Journal 2007, 43, 2699.

[96] Tian, Z. et al. Electrochimica Acta 2007, 52, 3199.

[97] Tien, C. P. et al. Electrochimica Acta 2008, 53, 4505.

[98] lieperuma,O.A. et al. Solar Energy Materials \& Solar Cells 2004, 84, 117.

[99] Cheng, C.L.et al. Journal of Power Sources 2004, 134, 202.

[100] Rajendran, S. et al. Journal Of Membrane Science 2008, 315, 67

[101] Hamaya, T. et al. Journal of Power Sources 2006, 156, 311.

[102] Xu, J.J. et al. Electrochemistry Communications 2005, 7, 829.

[103] Morita, M .et al. Journal of Power Sources 2005, 139, 351.

[104] Quio, J. et al. Electrochemistry Communications.2007, 9, 1945

[105] Rajendran, S. et al. Journal of Membrane Science 2008, 315, 67.

[106] Rajendran, S. et al. Journal Of Power Sources 2008, 180, 880.

[107] Gopalan, A.I. et al. Journal of Membrane Science 2008, 318, 422.

[108] Tien, C. P.; Liang, W. J.; Kuo, P. L.; Teng, H. S. Electrochimica Acta 2008, 53, 4505 .

[109] Krejza, O.; Velicka, J.; Vondrak, M. Journal of Power Sources, 2008, 178, 774.

[110] Wang, Y. J.; Kima, D. Journal of Membrane Science 2008, 31, 276.

[111] Chen, W.; Tang, H.; Ou, Z.; Wang, H.; Yang, Y. Electrochimica Acta 2007, 53, 2065.

[112] Rajendrana, S.; Sivakumara, P. Physica B, 2008, 403, 509. 
[113] Liang, Y. H.; Wang, C. C.; Chen, C. Y. Journal of Power Sources, 2008, 176, 340.

[114] Choi, J. A.; Eoa, S. M.; Douglas R. MacFarlane.; Forsyth, M.; Chad, E.; Kima, D. W. Journal of Power Sources 2008, 178, 832.

[115] Tien, C. P.; Liang, W. J.; Kuo, P. L.; Teng, H. S. Electrochimica Acta 2008, 53, 4505.

[116] Song, I. C.; Oh, J. S.; Kim, S. H.; Myounko, J.; Kim, D. W. Journal of Power Sources 2005, 50, 202.

[117] Zhang, S. S.; Ervin, M. H.; Xu, K.; Jow, T. R. Solid State lonics, 2005, 176, 41.

[118] Chauvin, C.; Alloin, F.; lojoiu, C.; Sanchez, J. Y. Electrochimica Acta 2006, 51, 5954.

[119] Dey, A.; Karan, S.; De, S. K. Solid State Ionics 2008, 178, 1963.

[120] Hassoun, J.; Croce, F.; Tizzani, C.; Scosati, B. Electrochemistry Communications, 2007, 9, 2045.

[121] Mazora, H.; Golodnitsky, D.; Peled, E.; Wieczorek, W.; Scrosati, B. Journal of Power Sources 2008, 178, 736.

[122] Stolarska, M.; Niedzicki, L.; Borkowska, R.; Zalewska*, A.; Wieczorek, W. Electrochimica Acta 2007, 53, 1512.

[123] Balakrishnan, P. G.; Ramesh, R.; Premkumar, T. Journal Of Power Sources 2006, 155, 401.

[124] Mallakpour, S.; Sepehri, S. Reactive and Functional Polymers 2008, 68, 1459.

[125] Pereiro, A. B.; Rodriguez, A. Separation \& Purification Technology 2008, 62, 733.

[126] Konig, A.; Stepanski, M.;.Kuszlik, A.; Keil, P.; Weller, C. Chemical Engineering Research\&Design 2008, 86, 775.

[127] Fu, C. et al. Electrochemistry Communications 2008, 10, 806.

[128] Noda, A.; Watanabe, M. Electrochimica Acta 2000, 45, 1265.

[129] Wilkes, J. S.; Zaworotko, M. J. J.Chem.Soc. Chem. Commun. 1992, 965.

[130] Koch, V. R.; Nanjundiah, C.; Appetecchi, G. B.; Scrosati, B. J.Electrochem. Soc. 1995, 142, L116.

[131] Hagiwara, R.; Hirashige, T.; Tsuda, T.; Ito, Y. J.Fluorine Chem. 1999, 99, 1

[132] Malham, I. B.; Letellier, P.; Turmine, M. Talanta 2008, 77, 48.

[133] Sun, W.; Wang, D.; Li, G.; Zhai, Z.; Zhao, R.;Jiao, Kui, J. Eectrochimica Acta 2008, 28, 8217.

[134] Xiao, F.; Ruan, C.; Liu, L.;Yan, R.; Zhao, F.; Zeng, B. Sensors \& Actuators B : Chemical 2008, 134, 895.

[135] Ohno, H.; Yoshizawa, M.; Ogihara, W. Electrochimica Acta 2003, 48, 2079.

[136] Byrne, N.; Howlett, P. C.; MacFarlane, D. R.; Smith, M. E.; Howes, A.; Hollenkamp, A. F.; Bastow, T.; Hale, P.; Forsyth, M. Journal of Power Sources 2008, 184, 288.

[137] Taggougui, M.; Diaw, M.; Carre, B.; Willmann, P.; Lemordant, D. Electrochimica Acta 2008, 53, 5496.

[138] Singh, B.; Hundal, M. S.; Park, G. G.; Park, J. S.; Lee, W. Y. ; Kim, C.S.; Yamada, K.; Sekhon, S. S. Solid State Ionics 2007, 178, 1404.

[139] Cheng, H.; Zhu, C.; Huang, B.; Lu, M.; Yang, Y. Electrochimica Acta 2007, 52, 5789 .

[140] Rupp, B.; Schmuck, M.; Balducci, A.; Winter, M.; Kern, W. European Polymer Journal 2008, 44(9) 2986.

[141] Yu, B.; Zhou, F.; Wang, C.; Liu, W. European Polymer Journal 2007, 43, 2699 
[142] Nguyen, D. Q.; Hwang, J.; Lee, J. S.; Kim, H.; Lee, H.; Cheong, M.; Lee, B.;Kim, H. S. Electrochemistry Communications 2007, 9, 109.

[143] Nguyen, D. Q.; Bae, H. W.; Jeon, E. H.; Lee, J. S. Cheong, M.; Kim, H.; Kim, H. S.; Lee, H. Journal of Power Sources 2008, 183,303

[144] Marwanta, E.; Mizumo, T.; Ohno, H. Solid State lonics 2007, 178, 227.

[145] Taggouguia, M.; Diawb, M.; Carre' a, B.; Willmannc, P.; Lemordant, D. Electrochimica Acta 2008, 53, 5496. 